\title{
Mining Wastes of an Albite Deposit as Raw Materials for Vitrified Mullite Ceramics
}

\author{
Pedro J. Sánchez-Soto ${ }^{1, *}$, Eduardo Garzón ${ }^{2}$, Luis Pérez-Villarejo ${ }^{3,4} \mathbb{D}$, George N. Angelopoulos 5 \\ and Dolores Eliche-Quesada ${ }^{3,4, * \text { (D) }}$ \\ 1 Institute of Materials Science of Sevilla (ICMS), Joint Center of the Spanish National Research \\ Council (CSIC)-University of Sevilla, 41092 Sevilla, Spain \\ 2 Department of Engineering, University of Almería, 04120 Almería, Spain; egarzon@ual.es \\ 3 Department of Chemical, Environmental and Materials Engineering, University of Jaén, 23071 Jaén, Spain; \\ lperezvi@ujaen.es \\ 4 Center for Advanced Studies in Earth Sciences, Energy and Environment (CEACTEMA), University of Jaén, \\ Campus Las Lagunillas s/n, 23071 Jaén, Spain \\ 5 Department of Chemical Engineering, University of Patras, 26504 Patras, Greece; angel@upatras.gr \\ * Correspondence: pedroji@icmse.csic.es (P.J.S.-S.); deliche@ujaen.es (D.E.-Q.)
}

Citation: Sánchez-Soto, P.J.; Garzón, E.; Pérez-Villarejo, L.; Angelopoulos, G.N.; Eliche-Quesada, D. Mining Wastes of an Albite Deposit as Raw Materials for Vitrified Mullite Ceramics. Minerals 2021, 11, 232. https://doi.org/10.3390/ $\min 11030232$

Academic Editor: Rolf Sjöblom

Received: 30 December 2020

Accepted: 20 February 2021

Published: 25 February 2021

Publisher's Note: MDPI stays neutral with regard to jurisdictional claims in published maps and institutional affiliations.

Copyright: (c) 2021 by the authors. Licensee MDPI, Basel, Switzerland. This article is an open access article distributed under the terms and conditions of the Creative Commons Attribution (CC BY) license (https:// creativecommons.org/licenses/by/ $4.0 /)$.

\begin{abstract}
In this work, an examination of mining wastes of an albite deposit in south Spain was carried out using X-ray Fluorescence (XRF), X-ray diffraction (XRD), particle size analysis, thermodilatometry and Differential Thermal Analysis (DTA) and Thermogravimetric (TG) analysis, followed by the determination of the main ceramic properties. The albite content in two selected samples was high (65-40 wt. \%), accompanied by quartz (25-40 wt. \%) and other minor minerals identified by XRD, mainly kaolinite, in agreement with the high content of silica and alumina determined by XRF. The content of $\mathrm{Na}_{2} \mathrm{O}$ was in the range 5.44-3.09 wt. \%, being associated with albite. The iron content was very low $(<0.75 \mathrm{wt}$. \%). The kaolinite content in the waste was estimated from $\sim 8$ to $32 \mathrm{wt}$. $\%$. The particle size analysis indicated values of $11-31 \mathrm{wt}$. $\%$ of particles $<63 \mu \mathrm{m}$. The ceramic properties of fired samples (1000-1350 ${ }^{\circ} \mathrm{C}$ ) showed progressive shrinkage by the thermal effect, with water absorption and open porosity almost at zero at $1200-1250^{\circ} \mathrm{C}$. At $1200^{\circ} \mathrm{C}$, the bulk density reached a maximum value of $2.38 \mathrm{~g} / \mathrm{cm}^{3}$. An abrupt change in the phase evolution by XRD was found from 1150 to $1200{ }^{\circ} \mathrm{C}$, with the disappearance of albite by melting in accordance with the predictions of the phase diagram $\mathrm{SiO}_{2}-\mathrm{Al}_{2} \mathrm{O}_{3}-\mathrm{Na}_{2} \mathrm{O}$ and the system albite-quartz. These fired materials contained as main crystalline phases quartz and mullite. Quartz was present in the raw samples and mullite was formed by decomposition of kaolinite. The observation of mullite forming needle-shape crystals was revealed by Scanning Electron Microscopy (SEM). The formation of fully densified and vitrified mullite materials by firing treatments was demonstrated.
\end{abstract}

Keywords: waste mining; albite; quartz; kaolinite; mullite; vitrified; sintering

\section{Introduction}

Mullite is an aluminosilicate with the nominal composition $3 \mathrm{Al}_{2} \mathrm{O}_{3} \cdot 2 \mathrm{SiO}_{2}(72 \mathrm{wt}$. \% $\mathrm{Al}_{2} \mathrm{O}_{3}$ and $28 \mathrm{wt}$. \% SiO 2 ), one of the most common crystalline phases in ceramics [1-6]. It is the only stable crystalline phase in the binary $\mathrm{Al}_{2} \mathrm{O}_{3}-\mathrm{SiO}_{2}$ system with a high melting point $\left(1830{ }^{\circ} \mathrm{C}\right)$ at normal pressure [1,2]. High-mullite content materials show excellent properties, such as good chemical and thermal stability, stability in oxidative atmospheres, high-temperature strength, creep resistance, high resistance to thermal shock, low density $\left(3.17 \mathrm{~g} / \mathrm{cm}^{3}\right)$, low expansion coefficient $\left(\sim 4.5 \times 10^{-6} \mathrm{~K}^{-1}\right)$, very high transmittance in the mid-Infrared range and retention of mechanical properties at elevated temperatures. Consequently, due to their outstanding properties, they are important as structural advanced materials for high-temperature engineering applications, being one of the most important refractory ceramic materials, as well as electronical, catalytical (substrate) and 
optical applications [1-14]. High-technical mullite-based refractories are valuable to use as kiln furniture and as the lining of high-temperature furnaces. Thus, several important industries use this kind of refractory, such as iron and steel, cement, catalysts, petrochemicals, glass and many other advanced functional applications $[4,6-8,10-12]$.

Mullite is a rare mineral in nature. In fact, it was found only as a scarce mineral at Mull island (Scotland), being the origin of its name as a mineral [2-6]. Therefore, mullite must be obtained by synthesis from Al-Si precursors. Naturally occurring hydroxyaluminosilicates (kaolinite, halloysite, pyrophyllite, sericite, etc.), aluminosilicates (kyanite, sillimanite, etc.) and raw clays containing these minerals produce mullite by thermal treatments [5,7,8,12-28]. It should be noted that the use of hydroxyaluminosilicates as mullite precursors needs the incorporation of $\mathrm{Al}_{2} \mathrm{O}_{3}$ to reach $72 \mathrm{wt}$. \%, producing a complete mullitization by reaction and reaction sintering of this $\mathrm{Al}_{2} \mathrm{O}_{3}$ with $\mathrm{SiO}_{2}$ contained in these hydroxyaluminosilicates. For instance, kaolinite $\left[2 \mathrm{SiO}_{2} \cdot \mathrm{Al}_{2} \mathrm{O}_{3} \cdot 2 \mathrm{H}_{2} \mathrm{O}\right.$ or $\left.\mathrm{Al}_{2} \mathrm{Si}_{2} \mathrm{O}_{5}(\mathrm{OH})_{4}\right]$ has a 1:1 layered structure of $\left(\mathrm{Si}_{2} \mathrm{O}_{5}\right)^{2-}$ and $\left[\mathrm{Al}_{2}(\mathrm{OH})_{4}\right]^{2+}$ molecular sheets $[5,13,16,28]$, with 39.8 mass $\% \mathrm{Al}_{2} \mathrm{O}_{3}, 46.38$ mass $\% \mathrm{SiO}_{2}$ and 13.9 mass $\% \mathrm{H}_{2} \mathrm{O}$ [28]. Therefore, the $\mathrm{Al}_{2} \mathrm{O}_{3}$ content must be increased, although if a partial reaction of mullitization takes place, mullite-corundum (mullite- $\alpha$-alumina) materials could be obtained [7,9,19-22,29,30].

The preparation of mullite and high-mullite materials by synthesis from different precursors has been extensively described in the scientific literature $[4,5,8-12,14,19-22$, $27,31]$. It is important to note that the use of pure chemicals, the high cost of some raw materials and limitations, such as inert atmospheres and organic solvents (in sol-gel methods, the use of alcoxides), are not appropriate for large-scale production of mullite materials. In this sense, the use of raw $\mathrm{Si}$-Al clays is the most attractive method of mullite synthesis, at relatively low cost, to reach the specific 3:2 mullite molar relation $\mathrm{Al}_{2} \mathrm{O}_{3}: \mathrm{SiO}_{2}$ with economic viability. An interesting alternative, with a reduction in costs, is the use of mullite precursors derived from industrial wastes with high contents of alumina and silica. Several reported investigations over the years focused on this subject, being recently presented in an interesting review paper on the synthesis of mullite ceramics from industrial wastes [32]. It was concluded that the analysis of this review could serve as a basis guide to develop mullite ceramics from industrial wastes for both technical and economic purposes. As pointed out by Choo et al. [32], the use of industrial wastes in the synthesis of mullite ceramics leads to other benefits, such as the energy and cost savings when these wastes are reutilized as an engineering material. Furthermore, the use of these industrial wastes can reduce the environmental risks. Some interesting examples of previous research used kaolin wastes and residues [32-38], although a majority of research papers focused on coal fly ash and slate wastes $[32,39,40]$. It should be noted that a previous study by the first author and co-workers reported the basic features of the processing of mullite and mullite-based ceramic composites from Al metal wastes [41-44].

The study of by-products of mining and mining wastes for the synthesis of mullite is very interesting [35-38]. For instance, the mining of tin ores by a gravel pump or by dredging produces a stable mineral suspension containing very fine particles as a waste, the so-called tin tailing slurry [45]. The very fine clay particles in the slurry settle to a compact sediment, as a waste, and water can be recycled in the process. This kind of solid waste contains a high proportion of kaolinite, which can be used for mullite preparation [46,47]. Thus, the development of this applied research towards higher-added-value products encourages optimized methods of enhancing the recycling and reuse of mining wastes.

On the other hand, feldspars are the most widespread mineral group in the world, forming around $60 \%$ of the Earth's crust [48,49]. These minerals contain alkalis and alumina, two components of interest found in some ceramics, such as porcelains, geopolymers and several other materials [16,50-54]. Na-K feldspars, considered as fluxes in ceramics, are important agents for densification because they lead to the formation of the liquid phase by firing, which will form glass in vitreous ceramic bodies $[52,54]$. Sodium feldspar $\left(\mathrm{NaAlSi}_{3} \mathrm{O}_{8}\right)$, the albite mineral, is a product of altered sienites $[55,56]$. 
In the present work, a large deposit of albite sands in south Spain produced by alteration from intrusive rocks is considered [57]. It has been observed that the mining wastes of this deposit are concentrated under the storage in air of the raw materials. These solid wastes can be considered a product collected after washing the albite sands under the effects of rainwater. They contain a fine fraction of the raw materials which is discharged. The objectives of this work are to study these wastes and to investigate the firing properties and the formation of mullite. It should be noted that this kind of waste has been not studied until now. Therefore, it could be of interest for the valorization of these wastes as ceramic raw materials.

\section{Materials and Methods}

An in situ examination of several samples of this albite deposit was performed. The selection was based on the residue after wet sieving using a $0.063 \mathrm{~mm}$ sieve and $100 \mathrm{~g}$ of each sample. The sample name was assigned as follows: $\mathrm{F}$ for feldspar; $\mathrm{Na}$ for the chemical symbol of sodium (sodium feldspar, albite); the number, 1, 2, etc., indicates the number of samples studied; and B is for basic examination.

After a previous wet sieving, FNa-1B was a sample without residue using the $0.063 \mathrm{~mm}$ sieve. A second sample, FNa-2B, was a sample with an estimation of residue of $3 \mathrm{wt}$. \%. Sample FNa-3B was a sample with a higher amount of residue, after wet sieving, with an estimation of $\sim 10 \mathrm{wt}$. \%. Sample FNa-4B was a sample with the highest amount of residue after wet sieving, with an estimation of $\sim 30 \mathrm{wt}$. \%. Finally, the sample designated FNa-5B was a sample with $\sim 10 \mathrm{wt}$. \% of residue after wet sieving, similar to sample FNa-3B, but the visual examination indicated that iron oxides were present at a high relative proportion. Therefore, it was discarded. This simple screening procedure was of great interest to select only two samples for further examination and characterization at the laboratory: FNa-3B and FNa-4B. Then, when fractions were obtained using several sieves at the laboratory, the capital letter " $\mathrm{B}$ " was changed to " $\mathrm{M}$ " to indicate "Mullite precursor". Two samples were obtained by wet sieving under $0.063 \mathrm{~mm}$ : FNa-3M and FNa-4M. They were wet sieved in batches of $1 \mathrm{~kg}$ each to pass $63 \mu \mathrm{m}$ and the resultant wet powders were air dried overnight and dried at $110{ }^{\circ} \mathrm{C}$ for $24 \mathrm{~h}$ (samples designated FNa-3M and FNa-4M).

The chemical analysis of all the samples was performed by X-ray fluorescence analysis (XRF) using ground powders prepared as pressed pellets using boric acid. The equipment was a Siemens SRS-3000 (Siemens AG, Munich, Germany) sequential XRF spectrometer with an Rh standard X-ray tube.

The mineralogical analysis of the samples was performed by X-ray powder diffraction (XRD). Samples were ground in an agate mortar. They were scanned in random preparations using an X-ray diffractometer, Siemens, D-501 model (Siemens AG, Munich, Germany), at $40 \mathrm{kV}$ and $20 \mathrm{~mA}$, with Ni-filtered $\mathrm{CuK} \alpha$ radiation and a graphite monochromator. The mineralogical composition of the samples was determined using the methods proposed by Schultz [58] and Biscaye [59]. These methods were applied in previous investigations by several authors [60-64]. From the X-ray diagnostic peaks of each crystalline mineral phase, the peak areas were measured. Several sources of errors that influence the shape of XRD diagrams, for instance, the orientation of layer silicates, the background and grinding of the samples, were avoided. The error expected in this estimation was $\pm 5 \%$ according to the $X$-ray profile selected for the determination. Mineral phases at a low relative proportion were indicated as $<5 \%$.

Particle size distribution of the samples after wet sieving was determined by sedimentation based on Stokes' law using the method of Andreasen following the experimental set up of the Spanish group of kaolins [65].

Test bars were prepared in a plaster of Paris molds. Dextrin (5 wt. \%) was mixed with the samples to increase the plasticity of the powders as an additive to prepare these bars. After drying at $110^{\circ} \mathrm{C}$ in an oven, the green test bars were subjected to dilatometric analysis using a Malkin BCRA (Malkin and Company Ltd., Stoke-on-Trent, UK) dilatometer in air, at a heating rate of $6{ }^{\circ} \mathrm{C} / \mathrm{min}$. After firing at $1000{ }^{\circ} \mathrm{C}$ for $1 \mathrm{~min}$, test bars were also subjected 
to further dilatometric analysis. Differential thermal analysis (DTA) and thermogravimetric (TG) analysis were carried out simultaneously using a Rigaku Thermal Analyzer, PTC10A model (Rigaku Corporation, Tokyo, Japan), with the data processor DPS-1. Ground samples (40 mg) using an agate mortar were packed in a platinum crucible and thermally treated in flowing air from 20 to $1200{ }^{\circ} \mathrm{C}(\mathrm{Pt} / \mathrm{Pt}-\mathrm{Rh} 13 \%$ thermocouples) at a heating rate of $12{ }^{\circ} \mathrm{C} \cdot \mathrm{min}^{-1}$. Cylindrical pellets for determination of ceramic properties were prepared by uniaxial dry pressing of the powders using $~ 5 \mathrm{wt}$ \% of distilled water, at $40 \mathrm{MPa}$. The pellets were air dried for $4 \mathrm{~h}$ and then treated at $60^{\circ} \mathrm{C}$ for $4 \mathrm{~h}$ using an oven. They were heated in air to selected temperatures, in the range $1000-1350{ }^{\circ} \mathrm{C}$ at $50{ }^{\circ} \mathrm{C}$ intervals, with $2 \mathrm{~h}$ of soaking time, and then furnace cooled. An electric laboratory furnace with $\mathrm{SiC}$ heating elements was used at a heating rate of $6^{\circ} \mathrm{C} / \mathrm{min}$. Linear firing shrinkage was obtained by measuring the length of the samples before and after the firing treatments using a caliper with a precision of $\pm 0.01 \mathrm{~mm}$. The weight loss after firing (\%) was determined as the mass loss between drying at $110^{\circ} \mathrm{C}$ and firing at several temperatures. Water absorption, bulk density and apparent or open porosity of the heated cylindrical pellets were measured by the Archimedes immersion technique, using distilled water, saturation for $24 \mathrm{~h}$ and boiling in distilled water for $2 \mathrm{~h}$. All the measurements were performed in triplicate. A portion of the heated samples was also ground and examined by XRD.

Microstructures of the fired samples at $1200{ }^{\circ} \mathrm{C}$ were examined on fresh fractures by scanning electron microscopy (SEM) after coating with a thin layer of gold by sputtering. The equipment was a JEOL microscope, model JSM-5400 (JEOL Ltd., Tokyo, Japan). The samples were examined after previous etching for $10 \mathrm{~min}$ in $20 \% \mathrm{HF}$ aqueous solution.

\section{Results and Discussion}

\subsection{Chemical Analysis by XRF of the Raw Samples and after Wet Sieving under $63 \mu \mathrm{m}$ Samples}

Table 1 shows the chemical analysis by XRF of the raw samples (FNa-3B and FNa$4 \mathrm{~B})$ and samples wet sieved to pass $63 \mu \mathrm{m}$ (FNa-3M and FNa-4B). All these samples present a high content of $\mathrm{SiO}_{2}(>60 \mathrm{wt}$. \%), associated with the albite present and possible quartz, being in the range 62.0-72.5 wt. \%. The $\mathrm{Al}_{2} \mathrm{O}_{3}$ content is medium, being in the range 18.7-25.1 wt. \%, and associated with combined silicates. The content of $\mathrm{Na}_{2} \mathrm{O}$ must correspond to albite present in the samples, with variable content in the range 3.09-5.44 wt. \%. The rest of the elements are not relevant. The iron content in the samples is relatively low, with a minimum value of $0.37 \mathrm{wt}$. \% in the sample FNa-4M and a maximum value in the sample FNa-3B. Finally, it should be noted that the values of weight loss after heating at $1000{ }^{\circ} \mathrm{C}$ (named "loss on ignition" = LOI) are in the range $1.08-4.45 \mathrm{wt}$ \% \%. This is an indication of other mineralogical components present in the samples, besides albite and quartz. Both of these minerals do not present any weight loss after heating when they are pure [53]. Then, assuming that all the weight loss is associated with kaolinite, an estimation of the kaolinite content is presented in Table 1. This estimation was performed on the basis of the 13.9 mass \% of structural water for pure kaolinite [28]. From these results, it can be observed that the sample with the higher kaolinite content is FNa-4M with $\sim 32 \mathrm{wt}$. \% of kaolinite, and the lower content ( $8 \mathrm{wt} . \%)$ is found for sample FNa-3B.

Table 1. Chemical analysis by XRF of the raw samples (FNa-3B and FNa-4B) and samples after wet sieving under $63 \mu \mathrm{m}$ (samples FNa-3M and FNa-4M). LOI = "loss on ignition", loss of weight after heating at $1000{ }^{\circ} \mathrm{C} / 1 \mathrm{~h}$. An estimation of kaolinite content has been included on the basis of LOI results (the LOI for pure kaolinite is $13.9 \mathrm{wt}$ \% [28]).

\begin{tabular}{ccccc}
\hline wt. $\%$ & FNa-3B & FNa-3M & FNa-4B & FNa-4M \\
\hline $\mathrm{SiO}_{2}$ & 72.30 & 68.11 & 72.51 & 62.02 \\
$\mathrm{Al}_{2} \mathrm{O}_{3}$ & 18.71 & 22.62 & 18.73 & 25.12 \\
$\mathrm{Fe}_{2} \mathrm{O}_{3}$ & 0.75 & 0.72 & 0.50 & 0.37 \\
$\mathrm{TiO}_{2}$ & 0.19 & 0.48 & 0.12 & 0.34 \\
$\mathrm{CaO}$ & 0.36 & 0.29 & 0.28 & 1.74 \\
$\mathrm{MgO}$ & 0.07 & 0.11 & 0.05 & 0.08 \\
\hline
\end{tabular}


Table 1. Cont.

\begin{tabular}{ccccc}
\hline wt. $\%$ & FNa-3B & FNa-3M & FNa-4B & FNa-4M \\
\hline $\mathrm{Na}_{2} \mathrm{O}$ & 5.44 & 3.09 & 4.58 & 4.84 \\
$\mathrm{~K}_{2} \mathrm{O}$ & 0.68 & 0.74 & 0.72 & 0.63 \\
LOI & 1.08 & 3.40 & 2.24 & 4.45 \\
Total & 99.58 & 99.56 & 99.73 & 99.59 \\
Kaolinite & $\sim 8$ & $\sim 25$ & $\sim 16$ & $\sim 32$ \\
\hline
\end{tabular}

\subsection{XRD of the Raw Samples and Samples after Wet Sieving under $63 \mu \mathrm{m}$}

Figure 1 displays the XRD mineralogical analysis of the raw samples and samples after wet sieving under $63 \mu \mathrm{m}$. According to the XRD results (Figure 1), quartz and albite $\left(\mathrm{AlNaSi}_{3} \mathrm{O}_{8}\right)$ as main phase minerals are present in all the samples. These results allow calculating the percentages of albite, being in the range 40-65 wt. \%, with 25-40 wt. \% of quartz and some accessory phase minerals (5-30 wt. \%), mainly kaolinite (Table 1), relicts of muscovite mica and possibly calcium-sodium feldspars. The kaolinite identified in these samples is of low crystallinity because broad X-ray peaks are observed, in accordance with previous results [57]. It has been verified by XRD that if the albite content increases, the content of quartz decreases. In this sense, some raw materials of the same deposit with a low albite content could be considered as $\mathrm{Na}$ feldspar sands. However, it should be noted that the boundary from feldspathic sand to silica sand varies from country to country [49].

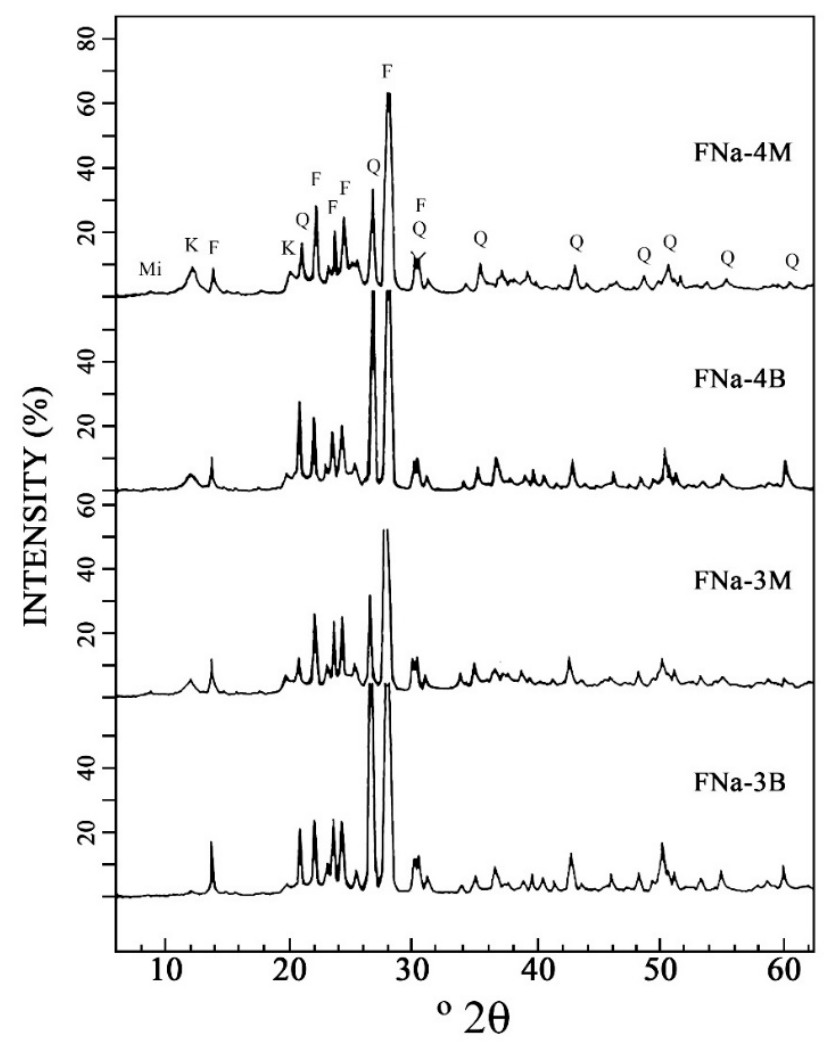

Figure 1. Mineralogical composition by XRD of the raw albite materials (FNa-3B and FNa-4B) and materials after wet sieving under $63 \mu \mathrm{m}$ (FNa-3M and FNa-4M). Q: quartz; F: felspar (albite); K: kaolinite; Mi: muscovite (illite).

\subsection{Particle Size Analysis of Samples by Wet Sieving}

The particle size analysis of raw samples and samples by wet sieving (Figure 2a,b) shows variable percentages of fractions lower than $2000 \mu \mathrm{m}$, with variations of $11-31$ wt. \% in the percentages of particles lower than $63 \mu \mathrm{m}$. Further analysis by sedimentation of this fraction (Figure 2c) indicates percentages of 10-20 wt. \% of the fraction lower than $2 \mu \mathrm{m}$. 
This result is in connection with the presence of variable amounts of kaolinite in the raw albite samples (Figure 1). In fact, as observed in Table 1, the samples FNa-3M and FNa-4M show the higher percentages of LOI, with this result being associated with the presence of kaolinite.
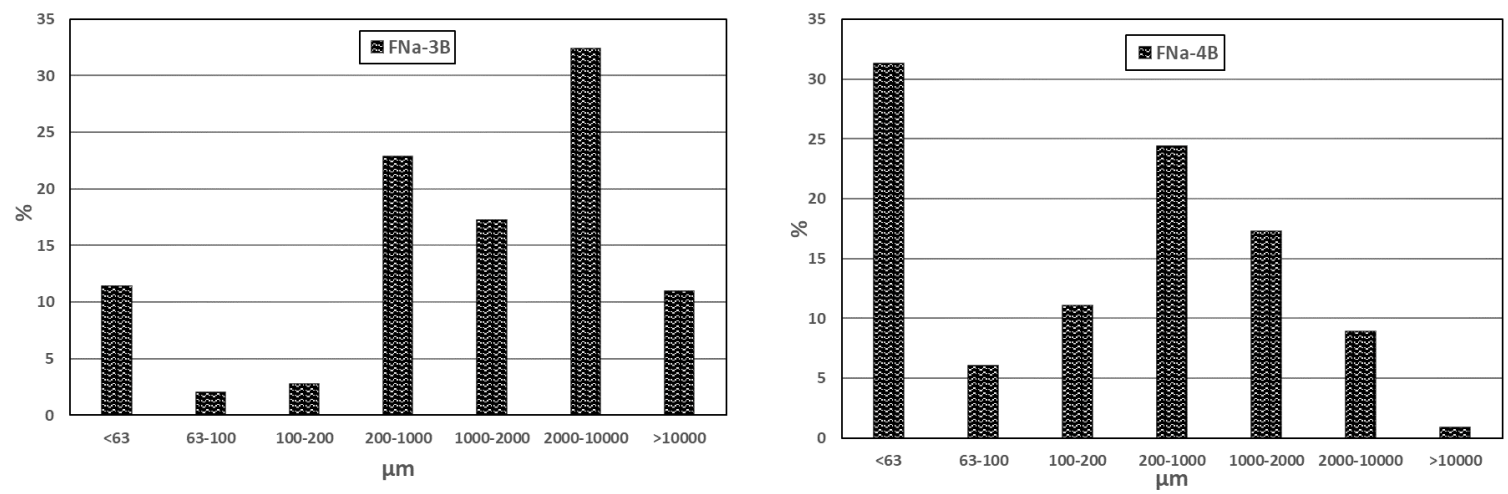

(a)
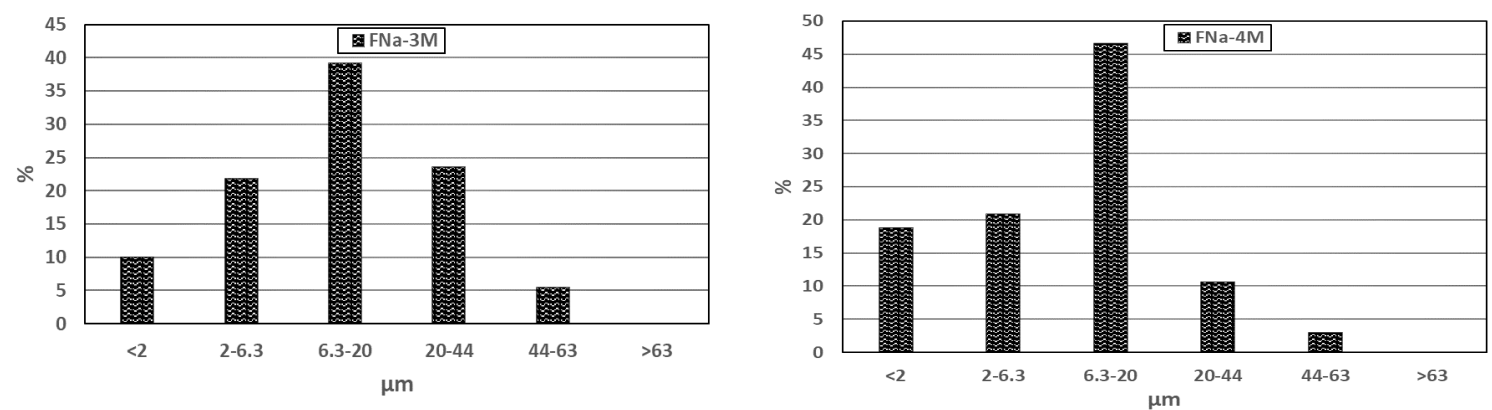

(b)

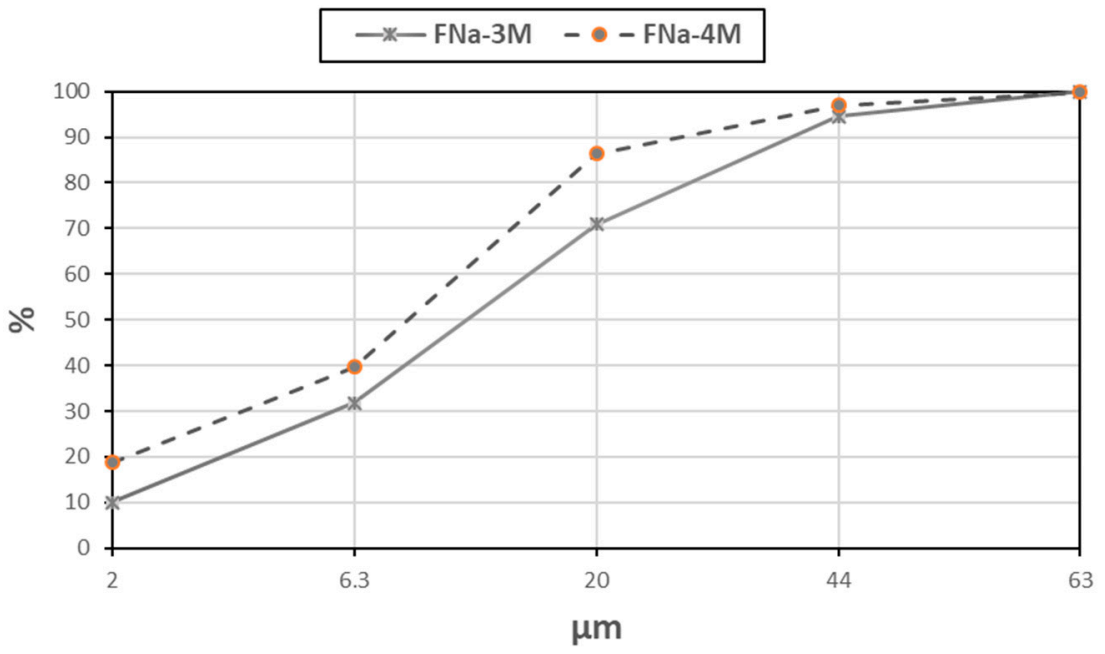

(c)

Figure 2. Particle size analyses of the raw albite: (a) histograms of wet sieving analysis of the raw samples; (b) histograms of sedimentation analysis of fraction $<63 \mu \mathrm{m}$; and (c) curves of particle size distribution obtained from the above results. 


\subsection{Thermal Analysis of Samples}

Figures 3 and 4 show the thermal analysis results of selected samples. Figure 3 shows the thermal dilatation curves for both green and fired $\left(1000^{\circ} \mathrm{C}\right)$ samples. The profiles of all the samples are very similar. A continuous linear expansion from room temperature with a change in the slope at 550 to $600{ }^{\circ} \mathrm{C}$ associated with the $\alpha$ to $\beta$ quartz phase transition can be seen in the samples [52-54,66]. Above $600{ }^{\circ} \mathrm{C}$, the linear expansion is continued, although the values are lower than at the starting of these run tests. The dilatometry curves for the test bars fired at $1000{ }^{\circ} \mathrm{C}$ show the quartz phase transition, being of lower intensity as expected in the case of the fraction $<63 \mu \mathrm{m}$.

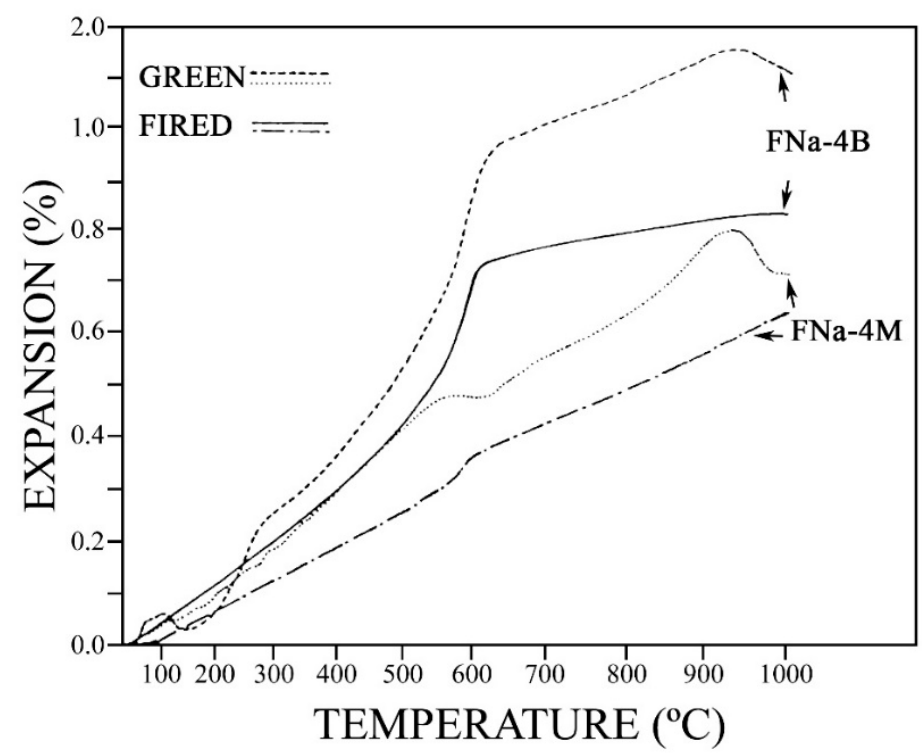

Figure 3. Thermal analysis results by dilatometry analysis in green and fired $\left(1000^{\circ} \mathrm{C}\right)$ states (heating rate $\left.6^{\circ} \mathrm{C} / \mathrm{min}\right)$.

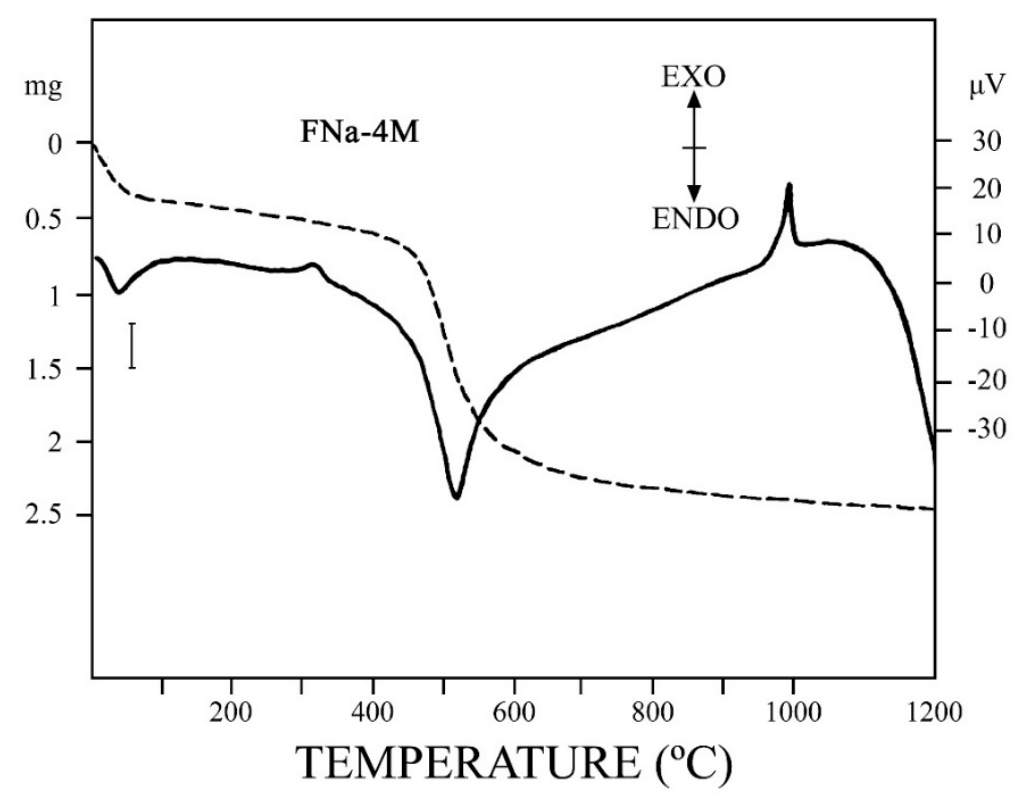

Figure 4. DTA-TG diagram of a selected sample (FNa-4M) obtained at $12{ }^{\circ} \mathrm{C} / \mathrm{min}$. (-DTA; — TG).

The above results are in relation to the DTA-TG diagrams (Figure 4). It should be noted that pure albite does not show weight loss by TG and the DTA trace without any changes between 50 and $1050{ }^{\circ} \mathrm{C}$ [53]. The thermal profile of sample FNa-4M is associated with the 
presence of kaolinite. In fact, this sample contains the higher percentage of kaolinite, as shown Figure 1 and Table 1 (with an estimation of $\sim 32 \mathrm{wt}$. \%). The profile is characteristic with a broad endothermic DTA effect at $530{ }^{\circ} \mathrm{C}$, with the main weight loss observed by TG, associated with the dehydroxylation of this silicate with loss of structural $\mathrm{OH}$ groups and formation of "metakaolinite" [5,13,16-18,22-26]. There is also a slight change in the slope of the DTA curve at $570{ }^{\circ} \mathrm{C}$ associated with the $\alpha$ to $\beta$ thermal phase transformation of quartz $[52,54,66]$. This thermal change was more evident by dilatometry (Figure 3 ).

There is a small DTA exothermic effect centered at $\sim 300{ }^{\circ} \mathrm{C}$. This effect could be associated with the presence of amorphous components, such as allophane or even iron oxy-hydroxide gels. At this point in time, the presence of both components is not clear, and it would need more experimental work. Allophane of the chemical composition $\mathrm{Al}_{2} \mathrm{O}_{3}\left(\mathrm{SiO}_{2}\right)_{\mathrm{x}} n \mathrm{H}_{2} \mathrm{O}$ with $x=1.3-2$ and $n=2.5-3$ is an amorphous component originated by weathering or the hydrothermal alteration product of volcanic glass and feldspars $[67,68]$. The presence of allophane in this feldspar deposit is possible. Therefore, the "loss on ignition" associated with kaolinite (see Table 1) would be modified to perform the estimation of the kaolinite content. On the other hand, the mass loss determined by TG is small ( $\sim 0.37$ wt. \%) when this DTA effect is observed. In a previous paper concerning the characterization of a waste washing solid product of mining granitic tin-bearing sands [46], a similar effect was observed by DTA at $350^{\circ} \mathrm{C}$. It was associated with the presence of amorphous iron oxide gels $\left(\mathrm{Fe}_{2} \mathrm{O}_{3}\right.$ obtained by chemical analysis was $5.13 \mathrm{wt}$. \%). The DTA profile of this solid product was typical of a kaolinitic sample. It should be noted that Romero-Gómez et al. [69] studied the thermal transformation of limonite, a mixture of $\mathrm{FeO}(\mathrm{OH}) n \mathrm{H}_{2} \mathrm{O}$ and $\alpha-\mathrm{FeO}(\mathrm{OH})$ or goethite. When this mineral is heated, a thermal transformation with weight loss is produced at $\sim 300{ }^{\circ} \mathrm{C}$, originating $\mathrm{Fe}_{2} \mathrm{O}_{3}$ (haematite).

The further decrease in mass loss observed by TG (Figure 4) could be associated with the loss of the last structural $\mathrm{OH}$ groups present in kaolinite. They would need higher temperatures to be completely eliminated from the structure of "amorphous metakaolinite" originated by the kaolinite thermal decomposition [13]. Estimation of kaolinite in this sample is $\sim 32 \mathrm{wt}$. \% (Table 1). The total weight loss by TG is $4.55 \mathrm{wt}$. \%, in agreement with the LOI value ( $4.45 \mathrm{wt}$. \%) presented in Table 1 for this sample.

The characteristic exothermic sharp DTA effect at $\sim 970{ }^{\circ} \mathrm{C}$ is associated with the decomposition of metakaolinite previously formed by heating $[5,13,16-18,26,27,47]$. This effect has been attributed to the formation of either mullite nuclei or a transient aluminatype spinel $\left(\gamma-\mathrm{Al}_{2} \mathrm{O}_{3}\right.$ solid solution) or both because at DTA heating rates, both mullite and spinel have the possibility of forming concurrently [5]. Finally, from 1000 to $1200{ }^{\circ} \mathrm{C}$, a progressive decrease in the DTA endothermal signal can be observed. It is associated with the progressive formation of the liquid phase from the albite present, with a shrinkage effect of the sample by sintering, with diminution of the thermal contact between the sample and crucible. It should be noted that under the dynamic heating conditions $\left(12{ }^{\circ} \mathrm{C} / \mathrm{min}\right)$ using the DTA furnace up to $1200^{\circ} \mathrm{C}$ and subsequent cooling in the furnace, the product of this treatment appeared sintered. The treated sample was easily separated from the crucible.

\subsection{Physical Properties of Fired Samples}

Table 2 shows the ceramic properties of the fired sample FNa-4M (for sample FNa-3M, they were similar) from 1000 to $1350{ }^{\circ} \mathrm{C}$. The progressive shrinkage of the fired sample up to a value of $10 \%$ at $1200{ }^{\circ} \mathrm{C}$ can be observed, which then decreased from this temperature. The water absorption changes from $22.80 \%$ at $1000{ }^{\circ} \mathrm{C}$ to minimum values $(0.03-0.07 \%)$ at $1200-1250{ }^{\circ} \mathrm{C}$. The apparent or open porosity follows a similar trend. The bulk density values increase from 1.62 at $1000{ }^{\circ} \mathrm{C}$ to a maximum value of $2.38 \mathrm{~g} / \mathrm{cm}^{3}$ at $1200{ }^{\circ} \mathrm{C}$. Linear firing shrinkage and bulk density were maximized by firing the sample at $120{ }^{\circ} \mathrm{C}$ for $2 \mathrm{~h}$. To illustrate this thermal evolution, Figure 5 shows a graphical plot of the variation in linear shrinkage and water absorption, both as a function of the firing temperature. Two parameters are of interest concerning the densification and sintering of the samples if the vitrification or range curves are considered [70], as follows: the vitrification temperature 
$(T v)$, or the temperature at which the apparent or open porosity becomes almost zero, and the temperature of the maximum of the apparent density $(T d)$. In this particular case, it is found that $T v=1200{ }^{\circ} \mathrm{C}=T d$.

Table 2. Results of technical determinations of weight loss (WL), linear firing shrinkage (LFS), water absorption (WA), bulk density (BD) and apparent or open porosity (AP) for the sample FNa-4M.

\begin{tabular}{cccccc}
\hline T $\left({ }^{\circ} \mathbf{C}\right)$ & WL (wt. $\%)$ & LFS $(\%)$ & WA $(\%)$ & BD $\left(\mathbf{g} / \mathbf{c m}^{\mathbf{3}}\right)$ & AP $(\%)$ \\
\hline 1000 & 4.20 & -0.80 & 22.80 & 1.62 & 36.93 \\
1050 & 4.35 & 0.01 & 24.23 & 1.60 & 38.76 \\
1100 & 4.40 & 0.60 & 20.34 & 1.70 & 34.58 \\
1150 & 4.32 & 6.42 & 9.34 & 2.04 & 19.05 \\
1200 & 4.28 & 10.01 & 0.07 & 2.38 & 0.17 \\
1250 & 4.30 & 9.41 & 0.03 & 2.29 & 0.07 \\
1300 & 4.25 & 8.73 & 0.07 & 2.18 & 0.15 \\
1350 & 4.42 & 7.80 & 0.12 & 2.16 & 0.26 \\
\hline
\end{tabular}

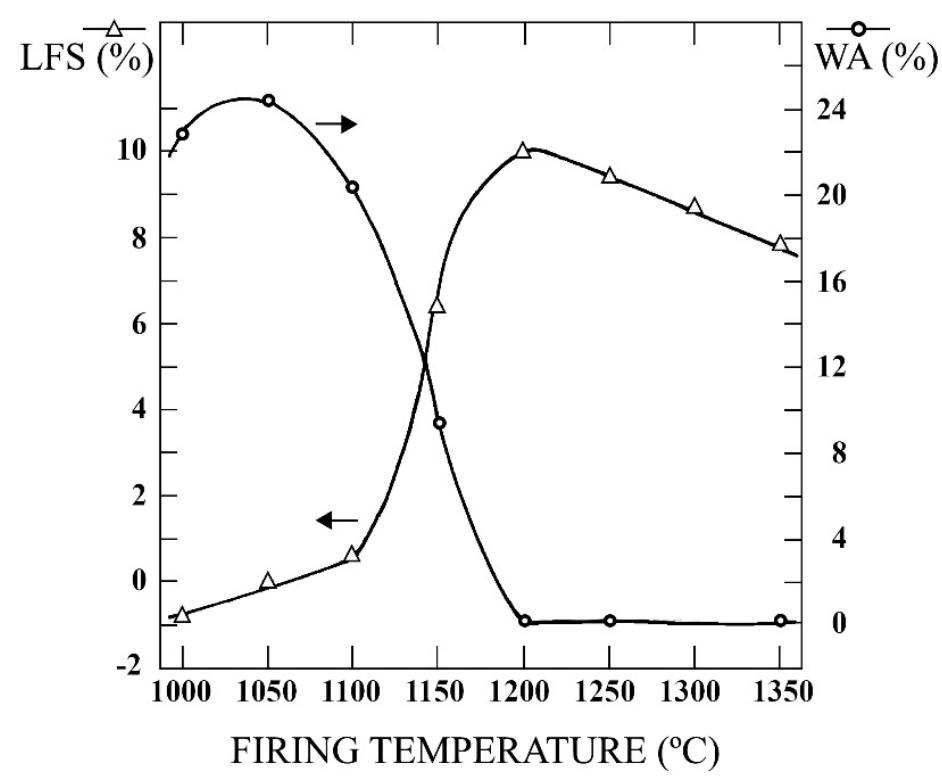

Figure 5. Thermal characteristic of the samples by firing: plot of the variation in linear shrinkage and water absorption as a function of firing temperature.

\subsection{XRD and SEM of Fired FNa-4M Sample}

Figure 6 shows the XRD diagrams of the sample FNa-4M after thermal treatments in the range $1000-1200{ }^{\circ} \mathrm{C}$ for $2 \mathrm{~h}$. Quartz, albite and the formation of mullite can be detected at $1100{ }^{\circ} \mathrm{C}$, with detection of several characteristic X-ray patterns, which increases in intensity as the firing temperature increases. An abrupt change is observed from 1150 to $1200{ }^{\circ} \mathrm{C}$, with disappearance of all the albite X-ray peaks associated with the melting of this phase. At $1200{ }^{\circ} \mathrm{C}$, quartz and mullite are the crystalline phases present in the fired sample besides the presence of the vitreous phase according to the increased hump of the XRD diagram. This result is in connection with the thermal evolution of the sample presented in Table 2 and Figure 5 and the previous DTA results (Figure 4). In fact, the equilibrium phase diagram $\mathrm{SiO}_{2}-\mathrm{Al}_{2} \mathrm{O}_{3}-\mathrm{Na}_{2} \mathrm{O}$ [71] indicates that the melting of albite $\left(\mathrm{Na}_{2} \mathrm{O} \cdot \mathrm{Al}_{2} \mathrm{O}_{3} \cdot 6 \mathrm{SiO}_{2}\right)$ is at $1118{ }^{\circ} \mathrm{C}$. The melting of $\mathrm{Na}$ feldspar was reported in the temperature range $1118-1160{ }^{\circ} \mathrm{C}$ [66]. Besides this, the Na feldspar composition of porcelain bodies exhibited the maximum densification at $1171^{\circ} \mathrm{C}[50]$ and the eutectic in the system albite-quartz has been found at $1060^{\circ} \mathrm{C}$ [72]. Celik [73] reported a melting point of $1170{ }^{\circ} \mathrm{C}$. In the same sense, Martin-Marquez et al. [51] reported a complete melting of feldspars (microcline and albite) used in the preparation of porcelain stoneware at $1200^{\circ} \mathrm{C}$. 


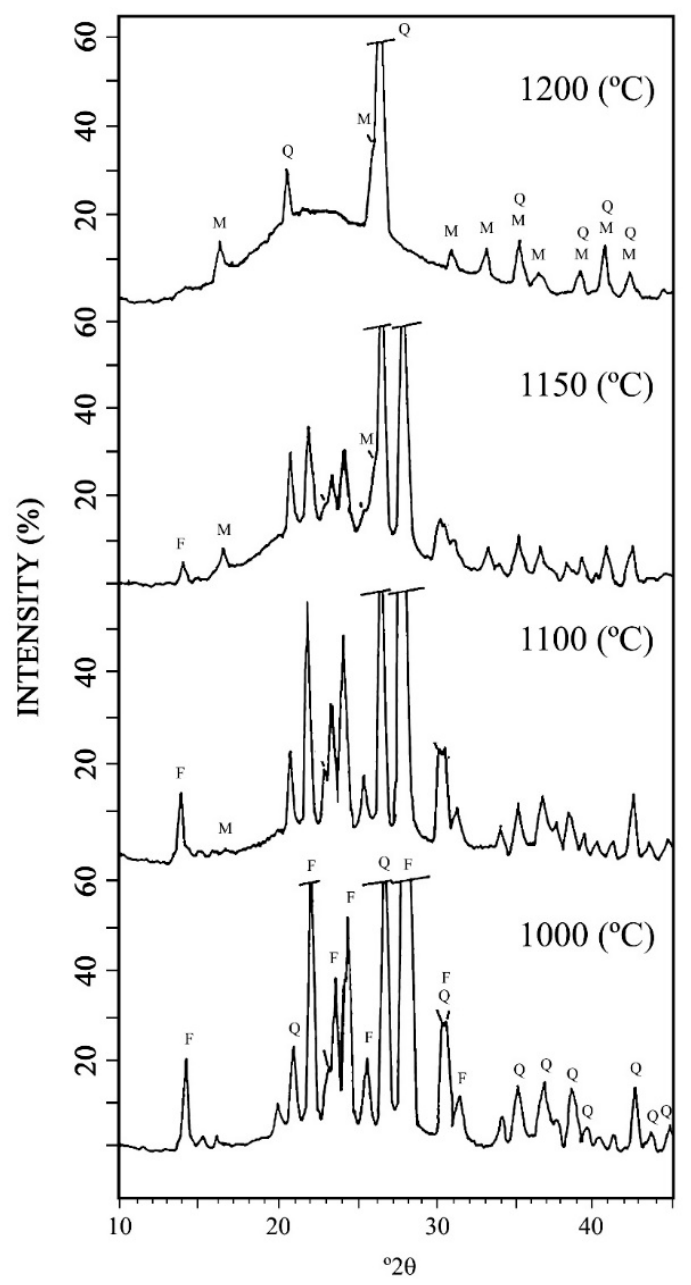

Figure 6. XRD diagrams of sample FNa-4M fired up to $1200{ }^{\circ} \mathrm{C}$. (Q: quartz; F: feldspar (albite); M: mullite.

On the other hand, Bernardo et al. [74] mentioned that alkali feldspar crystals (tectosilicates by the formula $\mathrm{M} \cdot \mathrm{AlSi}_{3} \mathrm{O}_{8}$, where $\mathrm{M}=\mathrm{Na}$ or $\mathrm{K}$, like albite) are known to provide excellent glasses but are unable to crystallize in practical periods of time. However, according to Dondi [49], the primary function of feldspathic fluxes is to melt during firing, thus providing a liquid phase that is responsible for viscous flow sintering and partial vitrification. It is clear that the presence of the Na-rich phase in the fired samples studied in this paper accelerates the vitrification process due to its fluxing effect. Furthermore, the amorphous silica produced during metakaolinite decomposition, being larger in this sample (kaolinite content $\sim 32 \mathrm{wt}$. \%, see Table 1), can also give rise to a vitreous phase formation.

Finally, the SEM observation of the sample FNa-4M fired at $1200{ }^{\circ} \mathrm{C}$ (Figure 7) shows a compacted microstructure with mullite crystals, which originated from kaolinite present in the sample (estimated at an amount of $\sim 32 \mathrm{wt}$. \%, see Table 1), showing needle shapes of small sizes, besides relicts of the glassy phase and quartz crystals, as expected from previous XRD results (Figure 6) when albite has disappeared. These findings are in agreement with previous SEM results of the literature concerning studies on vitreous bodies and porcelain stoneware [16,50-52,54]. 


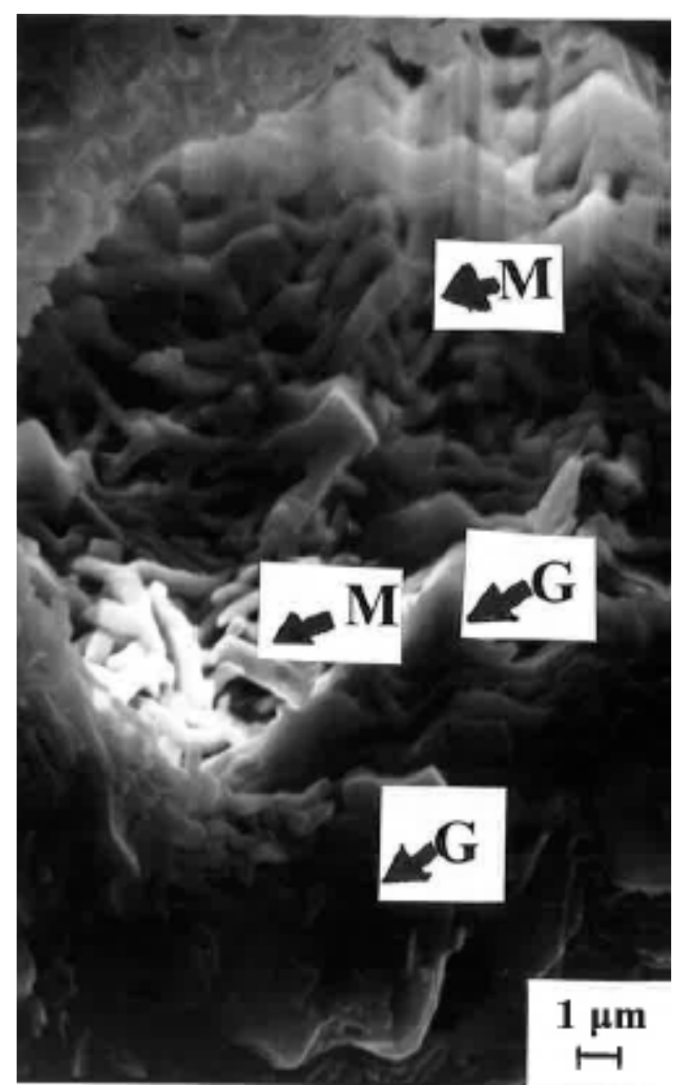

Figure 7. Selected SEM image of the sample FNa-4M fired at $1200{ }^{\circ} \mathrm{C}$ after chemical etching using $20 \% \mathrm{HF}$ aqueous solution. G indicates glassy phase and M mullite.

According to all these results, it can be mentioned that the amount of and variations in the wastes are a function of the raw albite with quartz processed at the deposit. At this time, the authors do not have access to any statistical data of production. The proprietary of the deposit has not revealed information concerning the production of albite sands, amount of mining wastes, cost of the mining products and other details. At the beginning, the interest of this research was focused on the finer fraction, where it was assumed that kaolin and kaolinized minerals, precursors of mullite, could be found. Then, the results of particle size analysis (Figure 2) indicated that variations of 11-31 wt. \% in the fraction lower than $63 \mu \mathrm{m}$ could be obtained. The clay fraction (lower than $2 \mu \mathrm{m}$ ), where kaolin minerals are present, is proportional to these contents, as demonstrated by the results obtained by sedimentation analysis (Figure 2c). The question is, therefore, as follows: why is this process the solution? A first solution was to consider the wastes of albite sand processing as mullite precursors, focusing on the size fractions lower than $63 \mu \mathrm{m}$, particularly "the clay fraction". Therefore, the product would be considered of added value as compared to albite and even quartz.

It was already mentioned that this kind of waste from an albite deposit has not been studied until now. The present paper is a preliminary report concerning several samples of this deposit. The formation of mullite was demonstrated in these samples by thermal treatment from $1100{ }^{\circ} \mathrm{C}$ (Figure 6). Furthermore, the microstructure developed by firing the selected fraction of this waste showed mullite crystals with the characteristic needle shape (Figure 7). Taking into account the precedent literature reports as mentioned in the Introduction section, the firing product $\left(1200^{\circ} \mathrm{C}\right)$ could be very interesting for advanced materials based on mullite. However, the content of elements distinct from silica and alumina $\left(3 \mathrm{Al}_{2} \mathrm{O}_{3} \cdot 2 \mathrm{SiO}_{2}\right.$, composition of mullite), as found by XRF analysis (Table 1 ), favored the formation of the vitreous phase, and besides this, the microstructure contains crystalline quartz. The vitreous phase is responsible for the sintering of the samples at temperatures that are relatively low $\left(1200{ }^{\circ} \mathrm{C}\right)$. Therefore, vitreous mullite ceramic bodies 
containing quartz, with the above microstructure, were the main finding according to the results of the present report. A future research work, under a contract with the proprietary of the albite deposit, will be performed for a wider and deeper study with new experimental findings and additional results. Consequently, a more complete study will be performed.

\section{Conclusions}

In this study, two representative samples of mining wastes of an albite deposit were examined. The content of albite was found by XRD in the range 40-65 wt. \%, with 25-40 wt. \% of quartz and accessory minerals, mainly kaolinite. The kaolinite content was of interest to produce mullite by firing. The $\mathrm{XRD}$ results agree with the high content of silica and alumina determined by $\mathrm{XRF}$, with $\mathrm{Na}_{2} \mathrm{O}$ contents in the range $3.09-5.44 \mathrm{wt}$. \% associated with albite in the samples, variable contents of silica and alumina, low weight loss in the range $1-4.5 \mathrm{wt}$. \% and low iron contents (<1 wt. \%).

The particle size analysis by wet sieving indicated: (a) variable percentages of fractions lower than $2000 \mu \mathrm{m}$, (b) percentages of 11-31 wt. \% in the percentages of particles $<63 \mu \mathrm{m}$ and (c) percentages of 10-20 wt. \% of fractions $<2 \mu \mathrm{m}$. In the finest fractions, kaolinite is concentrated, with an estimated amount of $\sim 8-32 \mathrm{wt}$. \%. The dilatometry curves showed the quartz phase transition, with a lower intensity of the profiles in the case of the fraction $<63 \mu \mathrm{m}$. Thermal analysis by DTA-TG allowed observing the kaolinitic character of this fine fraction, with a progressive effect of liquid formation and sintering mainly associated with the albite present.

The ceramic properties of fired samples $\left(1000-1350^{\circ} \mathrm{C}\right)$ showed progressive shrinkage by the thermal sintering effect, with water absorption and open porosity almost at zero at $1200-1250{ }^{\circ} \mathrm{C}$. Thus, fully densified vitrified materials by firing treatments can be obtained, being characterized by a nice white color because the iron content is very low. At $1200{ }^{\circ} \mathrm{C}$, the apparent density reached a maximum value of $2.38 \mathrm{~g} / \mathrm{cm}^{3}$. As a result of this behavior, it was found that $T v=1200{ }^{\circ} \mathrm{C}=T d$. The main change in the phase evolution was observed by XRD from 1150 to $1200^{\circ} \mathrm{C}$, with the disappearance of albite by melting in accordance with previous studies, the predictions of the phase diagram $\mathrm{SiO}_{2}-\mathrm{Al}_{2} \mathrm{O}_{3}-\mathrm{Na}_{2} \mathrm{O}$ and the binary system albite-quartz. The development of mullite crystals was evidenced by XRD. At $1200{ }^{\circ} \mathrm{C}$, quartz and mullite were found in the fired material besides the presence of the vitreous phase, as detected by XRD, and the needle shape of mullite crystals observed by SEM. These findings will be of interest when kaolinite wastes are used for the preparation of vitrified mullite ceramics. Further studies on this subject will be considered taking into account the present results.

Author Contributions: P.J.S.-S.: writing-original draft preparation, providing the samples at the deposit, performing some determinations and ceramic tests, analyzing data and designing the research. E.G.: performing some determinations, analyzing data and discussing results, preparing some figures and writing the paper. L.P.-V.: formal analysis, revising the results, analyzing data and writing original draft. G.N.A.: supervision, writing, review and editing. D.E.-Q.: analyses, writing-original draft, data curation, formal analysis and discussing the paper. All authors have read and agreed to the published version of the manuscript.

Funding: This research was supported by Junta de Andalucía through Research Group TEP 204 (Head of the group: P.J.S.-S.).

Institutional Review Board Statement: Not applicable.

Informed Consent Statement: Not applicable.

Data Availability Statement: Not applicable.

Acknowledgments: The contribution of D. Sergio Martínez-Martínez in the preparation of some figures presented in this paper is acknowledged.

Conflicts of Interest: The authors declare no conflict of interest. 


\section{References}

1. Davis, R.F.; Pask, J.A. Diffusion and Reaction Studies in the System $\mathrm{Al}_{2} \mathrm{O}_{3}-\mathrm{SiO}_{2}$. J. Am. Ceram. Soc. 1972, 55, 525-531. [CrossRef]

2. Aksay, I.A.; Pask, J.A. Stable and metastable equilibrium in the system $\mathrm{SiO}_{2}-\mathrm{Al}_{2} \mathrm{O}_{3}$. J. Am. Ceram. Soc. 1975, 58, 507-512. [CrossRef]

3. Peretz, I.; Bradt, R.C. Linear thermal expansion coefficients of mullite-matrix aluminosilicate refractory bodies. J. Am. Ceram. Soc. 1983, 66, 823-829. [CrossRef]

4. Aksay, I.A.; Dabbs, D.M.; Sarikaya, M. Mullite for structural, electronic and optical applications. J. Am. Ceram. Soc. 1991, 74, 2343-2354. [CrossRef]

5. Pask, J.A.; Tomsia, A.P. Formation of mullite form sol-gel mixtures and kaolinite. J. Am. Ceram. Soc. 1991, 74, 2367-2373. [CrossRef]

6. Schneider, H.; Okada, K.; Pask, J.A. Mullite and Mullite Ceramics; Wiley: Chichester, UK, 1994.

7. Schneider, H.; Komarneni, S. Mullite; Wiley-VCH Verlag GmbH \& Co.: Weinheim, Germany, 2005.

8. Schneider, H.; Schreuer, J.; Hildmann, B. Structure and properties of mullite-a review. J. Eur. Ceram. Soc. 2008, 28, 329-344. [CrossRef]

9. Sacks, M.D.; Bozkurt, N.; Scheiffele, G.W. Fabrication of mullite and mullite-matrix composites by transient viscous sintering of composite powders. J. Am. Ceram. Soc. 1991, 74, 2428-2437. [CrossRef]

10. Requena, J.; Bartolomé, J.F.; Moya, J.S.; De Aza, S.; Guitián, F.; Thomas, G. Mullite-aluminosilicate glassy matrix substrates obtained by reactive coating. J. Eur. Ceram. Soc. 1996, 16, 249-254. [CrossRef]

11. Ebadzadeh, T. Formation of mullite from precursor powders: Sintering, microstructure and mechanical properties. Mater. Sci. Eng. A. 2003, 355, 56-61. [CrossRef]

12. Ganesh, I.; Ferreira, J.M.F. Influence of raw material type and of the overall chemical composition of phase formation and sintered microstructure of mullite aggregates. Ceram. Int. 2009, 35, 2007-2015. [CrossRef]

13. Sanz, J.; Madani, A.; Serratosa, J.M.; Moya, J.S.; De Aza, S. Aluminum-27 and Silicon-29 MAS NMR study of the kaolinite-mullite transformation. J. Am. Ceram. Soc. 1988, 70, 837-842.

14. Sacks, M.D.; Lee, H.W.; Pask, J.A. A review of powder preparation methods and densification procedures for fabricating high density mullite. In Mullite and Mullite Matrix Composites; Davis, R.F., Pask, J.A., Somiya, S., Eds.; The American Ceramic Society: Westerville, OH, USA, 1990.

15. Gualteri, A.; Bertolani, M. Mullite and cristobalite formation in fired products starting from halloysite clay. Appl. Clay Sci. 1992, 7, 251-262. [CrossRef]

16. Carty, W.M.; Senapati, U. Porcelain-Raw Materials, Processing, Phase Evolution and Mechanical Behavior. J. Am. Ceram. Soc. 1998, 81, 3-20. [CrossRef]

17. Sánchez-Soto, P.J.; Pérez-Rodríguez, J.L.; Sobrados, I.; Sanz, J. Influence of grinding in pyrophyllite-mullite thermal transformation assessed by 29Si and 27Al MAS-NMR spectroscopies. Chem. Mater. 1997, 9, 677-684. [CrossRef]

18. Castelein, O.; Soulestin, B.; Bonnet, J.; Blanchart, P. The influence of heating rate on the thermal behavior and mullite formation from a kaolin raw material. Ceram. Int. 2001, 27, 517-522. [CrossRef]

19. Liu, K.C.; Thomas, G.; Caballero, A.; Moya, J.S.; De Aza, S. Mullite formation in kaolinite-Al ${ }_{2} \mathrm{O}_{3}$. Acta Met. Mater. 1994, 42, 489-495. [CrossRef]

20. Liu, K.C.; Thomas, G.; Caballero, A.; Moya, J.S.; De Aza, S. Time-temperature-transformation curves for kaolinite- $\alpha$-alumina. J. Am. Ceram. Soc. 1994, 77, 1545-1552. [CrossRef]

21. Wang, K.; Sacks, M.D. Mullite formation by endothermic reaction of $\alpha$-alumina/silica microcomposite particles. J. Am. Ceram. Soc. 1996, 79, 12-16. [CrossRef]

22. Yamuna, A.; Devanarayanan, S.; Latithambika, M. Phase-pure mullite from kaolinite. J. Am. Ceram. Soc. 2002, 85, 1409-1413. [CrossRef]

23. Tripathi, H.S.; Mukherjee, B.; Das, S.K.; Ghosh, A.; Banerjee, G. Effect of sillimanite beach sand composition on mullitization and properties of $\mathrm{Al}_{2} \mathrm{O}_{3}-\mathrm{SiO}_{2}$ system. Bull. Mater. Sci. 2003, 26, 217-220. [CrossRef]

24. Panneerselvam, M.; Rao, K.J. Novel microwave method for the synthesis and sintering of mullite from kaolinite. Chem. Mater. 2003, 15, 2247-2252. [CrossRef]

25. Chen, Y.F.; Wang, M.C.; Hon, M.H. Phase transformation and growth of mullite in kaolin ceramics. J. Eur. Ceram. Soc. 2004, 24, 2389-2397. [CrossRef]

26. Okada, K. Activation energy of mullitization from various starting materials. J. Eur. Ceram. Soc. 2008, 28, 377-382. [CrossRef]

27. González-Miranda, F.M.; Garzón, E.; Reca, J.; Pérez-Villarejo, L.; Martínez-Martínez, S.; Sánchez-Soto, P.J. Thermal behavior of sericite clays as precursors of mullite materials. J. Anal. Calorim. 2018, 132, 967-977. [CrossRef]

28. Hammas, A.; Lecomte-Nana, G.; Daou, I.; Tessier-Doyen, N.; Peyratout, C.; Zibouche, F. Kaolinite-Magnesite or Kaolinite-TalcBased Ceramics. Part II: Microstructure and the Final Properties Related Sintered Tapes. Minerals 2020, 10, 1080. [CrossRef]

29. Xu, G.; Ma, Y.; Cui, H.; Ruan, G.; Zhang, Z.; Zhao, H. Preparation of porous mullite-corundum ceramics with controlled pore size using bioactive yeast as pore-forming agent. Mater. Lett. 2014, 116, 349-352. [CrossRef]

30. Wang, X.; Li, J.H.; Guan, W.M.; Fu, M.J.; Liu, L.J. Emulsion-templated high porosity mullite-corundum ceramics with sericite induced textured structures. Mater. Des. 2016, 89, 1041-1047. [CrossRef] 
31. Cividanes, L.S.; Campos, T.M.B.; Rodrigues, L.A.; Brunelli, D.D.; Thim, G.P. Review of mullite synthesis routes by sol-gel method. J. Sol Gel Sci. Technol. 2010, 55, 111-125. [CrossRef]

32. Choo, T.F.; Salleh, M.A.M.; Kok, K.Y.; Matori, K.A. A Review on Synthesis of Mullite Ceramics from Industrial Wastes. Recycling 2019, 4, 39. [CrossRef]

33. Khalil, N.M.; Algamal, Y. Recycling of ceramic wastes for the production of high performance mullite refractories. Silicon 2020, 12, 1557-1565. [CrossRef]

34. Martins, I.M.; Sousa, J.B.; Catarino, L.; Vieira, M.T.; Oliveira, M. The formation of mullite from rock wastes containing alumina and silica. Key Eng. Mater. 2002, 230, 380-383. [CrossRef]

35. Brasileiro, M.I.; Menezes, R.R.; Farias, M.O.; Lira, H.R.; Neves, G.A.; Santana, L.N.L. Use of kaolin processing waste for the production of mullite bodies. Mater. Sci. Forum 2008, 591-593, 799-804. [CrossRef]

36. Menezes, R.R.; Farias, F.F.; Oliveira, M.F.; Santana, L.N.L.; Neves, G.A.; Lira, H.L.; Ferreira, H.C. Kaolin processing waste applied in the manufacturing of ceramic tiles and mullite bodies. Waste Manag. Res. 2009, 27, 78-86. [CrossRef]

37. Alves, H.P.A.; Silva, J.B.; Campos, L.F.A.; Torres, S.M.; Dutra, R.P.S.; Macedo, D.A. Preparation of mullite based ceramics from clay-kaolin waste mixtures. Ceram. Int. 2016, 42, 19086-19090. [CrossRef]

38. Choo, T.F.; Murshidi, J.A.; Saidin, N.U.; Paulus, W.; Abdullah, Y. Production of mullite ceramic bodies from kaolin processing waste and aluminum hydroxide. Mater. Sci. Forum 2017, 888, 81-85. [CrossRef]

39. Cao, J.; Dong, X.; Li, L.; Dong, Y.; Hampshire, S. Recycling of waste fly ash for production of porous mullite ceramic membrane supports with increasing porosity. J. Eur. Ceram. Soc. 2014, 34, 3181-3194. [CrossRef]

40. Choo, T.F.; Salleh, M.A.M.; Kok, K.Y.; Matori, K.A. Mineralogy and thermal expansion study of mullite-based ceramics synthesized from coal fly ash and aluminum dross industrial wastes. Ceram. Int. 2019, 45, 884-890.

41. Pascual, J.; Zapatero, J.; Sánchez-Soto, P.J.; Jiménez, M.C.; Justo, A.; Pérez-Rodríguez, J.L. Procedimiento para la obtención de materiales cerámicos porosos compuestos de mullita en forma de fibras cortas monocristalinas. Spanish Patent P009801122 1998.

42. Pascual, J.; Zapatero, J.; Jiménez de Haro, M.C.; Varona, I.; Justo, A.; Pérez-Rodríguez, J.L.; Sánchez-Soto, P.J. Porous mullite and mullite-based composites by chemical processing of kaolinite and aluminium metal wastes. J. Mater. Chem. 2000, 10, 1409-1414. [CrossRef]

43. Pascual, J.; Zapatero, J.; Jiménez de Haro, M.C.; Ramírez del Valle, A.J.; Pérez-Rodríguez, J.L.; Sánchez-Soto, P.J. Preparation of mullite ceramics from coprecipitated aluminum hydroxide and kaolinite using hexamethylenediamine. J. Am. Ceram. Soc. 2000, 83, 2677-2680. [CrossRef]

44. Ruiz-Conde, A.; Pascual, J.; Garzón, E.; Morales, L.; Raigón, M.; Sánchez-Soto, P.J. Processing of mullite and mullite-based ceramic composites from metal wastes and by-products of mining. In Proceedings of the 1st Spanish National Conference on Advances in Materials Recycling and Eco-Energy, Madrid, Spain, 12-13 November 2009; pp. 144-147.

45. Chang, Y.K.; Ho, C.C.; Lee, K.C.; Yeap, E.B. Physicochemical characterization of tin tailings slurries. Appl. Clay Sci. 1994, 9, 83-96. [CrossRef]

46. Raigón-Pichardo, M.; García-Ramos, G.; Sánchez-Soto, P.J. Characterization of a waste washing solid product of mining granitic tin-bearing sands and its application as ceramic raw material. Resour. Conserv. Recycl. 1996, 17, 109-124. [CrossRef]

47. Sánchez-Soto, P.J.; Eliche-Quesada, D.; Martínez-Martínez, S.; Garzón, E.; Pérez-Villarejo, L.; Rincón, J.M. The effect of vitreous phase on mullite and mullite-based ceramic composites from kaolin wastes as by-products of mining, sericite clays and kaolinite. Mater. Lett. 2018, 223, 154-158. [CrossRef]

48. Deer, W.A.; Howie, R.A.; Zussman, J. An Introduction to the Rock-Forming Minerals; Longman: Hong Kong, China, 1992.

49. Dondi, M. Feldspathic fluxes for ceramics: Sources, production trends and technological value. Resour. Conserv. Recycl. 2018, 133, 191-205. [CrossRef]

50. Das, S.K.; Dana, K. Differences in densification behaviour of K- and Na-feldspar-containing porcelain bodies. Acta 2003, 406, 199-206. [CrossRef]

51. Martin-Marquez, J.; De la Torre, A.G.; Aranda, M.A.G.; Rincón, J.M.; Romero, M. Evolution with temperature of crystalline and amorphous phases in porcelain stoneware. J. Am. Ceram. Soc. 2009, 92, 229-234. [CrossRef]

52. Bernasconi, A.; Diella, V.; Pagani, A.; Pavese, A.; Francescon, F.; Young, K.; Stuart, J.; Tunnicliffe, L. The role of firing temperature, firing time and quartz grain size on phase-formation, thermal dilatation and water absorption in sanitary-ware vitreous bodies. J. Eur. Ceram. Soc. 2011, 31, 1353-1360. [CrossRef]

53. Feng, D.; Provis, J.L.; van Deventer, J.S.J. Thermal activation of albite for the synthesis of one-part mix geopolymers. J. Am. Ceram. Soc. 2012, 95, 565-572. [CrossRef]

54. Bernasconi, A.; Marinoni, N.; Pavese, A.; Francescon, F.; Young, K. Feldspar and firing cycle effects on the evolution of sanitaryware vitreous body. Ceram. Int. 2014, 40, 6389-6398. [CrossRef]

55. Waldron, K.A.; Parsons, I. Feldspar microtextures and multistage thermal history of syenites from the Coldwell Complex, Ontario. Contrib. Miner. Pet. 1992, 111, 222-234. [CrossRef]

56. Schoene, B.; Bowring, S.A. U-Pb systematics of the McClure Mountain syenite: Thermochronological constrains on the age of the 40Ar/39Ar standard MMhb. Contrib. Miner. Pet. 2006, 151, 615-630. [CrossRef]

57. Poyato, J.; Pérez-Rodríguez, J.L.; García-Ramos, G.; González-García, F. Contribution to the knowledge of kaolin deposits of West Andalusia. In Proceedings of the 8th International Kaolin Symposium and Meeting on Alunite, Madrid, Roma, 7-16 September 1977; pp. 1-15. 
58. Schultz, L.G. Quantitative interpretation of mineralogical composition from X-ray and chemical data for the Pierre Shale. US Geol. Surv. Prof. Pap. 1964, 391C. [CrossRef]

59. Biscaye, P.E. Mineralogy and sedimentation of recent deep-sea clay in the Atlantic ocean and adjacent sea and oceans. Geol. Soc. Am. Bull. 1965, 76, 803-831. [CrossRef]

60. López, F.; Galán, E.; Martín, J.L. Sobre la mineralogía y génesis de dos yacimientos de caolín en la provincia de Valencia. Estud. Geol. 1971, 27, 145-152.

61. Jordán, M.M.; Boix, A.; Sanfeliú, T.; De la Fuente, C. Firing transformations of Cretaceous clays used in the manufacturing of ceramic tiles. Appl. Clay Sci. 1999, 14, 225-234. [CrossRef]

62. Dolinar, B.; Mišič, M.; Trauner, L. Correlation between surface area and Atterberg limits of fine-grained soils. Clays Clay Miner. 2007, 55, 519-523. [CrossRef]

63. Carretero, M.I.; Pozo, M.; Legido, J.L.; Fernández-González, M.V.; Delgado, R.; Gómez, I.; Armijo, F.; Maraver, F. Assessment of three Spanish clays for their use in pelotherapy. Appl. Clay Sci. 2014, 99, 131-143. [CrossRef]

64. Garzón, E.; Sánchez-Soto, P.J. An improved method for determining the external specific surface area and the plasticity of clayey samples based on a simplified method for non-swelling fine-grained soils. Appl. Clay Sci. 2015, 115, 97-107. [CrossRef]

65. Galán, E.; Espinosa de los Monteros, J. El Caolín en España. Características, Identificación y Ensayos Cerámicos; SECV: Madrid, Spain, 1975.

66. Ryan, W. Properties of Ceramic Raw Materials, 2nd ed.; Pergamon Press: North Staffordshire Polytechnic, UK, 1978.

67. Parfitt, R.L.; Kimble, J.M. Conditions for formation of allophane in soils. Soil Sci. Am. J. 1989, 53, 971-977. [CrossRef]

68. Farmer, V.C.; Russell, J.D. The structure and genesis of allophane and imogolite; their distribution in non-volcanic soils. In Soil Colloids and Their Association in Soil Aggregates; NATO Advanced Studies Workshop: Ghent, Belgium; Plenum: New York, NY, USA, 1985.

69. Romero-González, P.; González, J.C.; Bustamante, A.; Ruiz-Conde, A.; Sánchez-Soto, P.J. Study in situ of the thermal transformation of limonite used as pigment coming from Perú. Bol. Soc. Esp. Ceram. Vidr. 2013, 52, 127-131.

70. Norris, A.W.; Taylor, D.; Thorpe, I. Range curves: An experimental method for the study of vitreous pottery bodies. Br. Ceram. Trans. J. 1979, 78, 102-108.

71. Osborn, E.F.; Muan, A. System $\mathrm{SiO}_{2}-\mathrm{Al}_{2} \mathrm{O}_{3}-\mathrm{Na}_{2}$ O. In Phase Diagrams for Ceramists; Plate 501; The American Ceramic Society: Columbus, OH, USA, 1964; p. 181.

72. Simakin, A.G.; Rincón, J.M. Structural thermodynamic model of the melt in the system albite $\left(\mathrm{NaAlSi}_{3} \mathrm{O}_{8}\right)-q u a r t z\left(\mathrm{SiO}_{2}\right)[\mathrm{Ab}-\mathrm{Q}]$. Phys. Chem. Glasses 2002, 43, 184-188.

73. Celik, H. Technological characterization and industrial application of two Turkish clays for the ceramic industry. Appl. Clay Sci. 2010, 50, 245-254. [CrossRef]

74. Bernardo, E.; Doyle, J.; Hampshire, S. Sintered feldspar glass-ceramics and glass-ceramic matrix composites. Ceram. Int. 2008, 34, 2037-2042. [CrossRef] 